\title{
EVALUASI PROGRAM KELAS UNGGULAN DI MADRASAH IBTIDAIYAH (MIN) PUNIA MATARAM
}

\section{Maimun*}

\begin{abstract}
Abstrak: Artikel ini berupaya mengemukakan hasil evaluasi atas efektivitas penyelenggaraan pembelajaran Kelas Unggulan di Madrasah Ibtidaiyah Negeri (MIN) Punia Mataram. Untuk mengukur efektivitas penyelenggaraan Program secara konprehensif maka evaluasi menggunakan model CIPP (Contexs, Input, Process, dan Product). Hasil Evaluasi menunjukkan: 1) Program ini dilatari oleh keinginan pihak sekolah agar supaya anak-anak didik yang memiliki prestasi dapat dikumpulkan menjadi satu, sehingga akan mendapatkan output yang maksimal. 2) Pelaksanaan program kelas unggulan di MIN Punia diawali dengan melakukan sosialisasi program kelas unggulan secara terbatas di internal guru. Selanjutnya pihak sekolah mengundang orang tua murid dalam rangka sosialisasi pembentukan kelas unggulan. Pelaksanaan pembelajaran di kelas unggulan tidak jauh berbeda dengan kelas regular, hanya saja kelas unggulan mendapatkan jam belajar tambahan pada sore hari. 3) Terdapat perbedaan hasil belajar siswa sebelum dan setelah berlangsungnya kelas unggulan. Keberadaan kelas unggulan juga dapat menjadikan siswa lebih giat dalam berkompetisi dengan temannya.
\end{abstract}

Kata Kunci: evaluasi program, evaluasi model CIPP, kelas unggulan, madrasah ibtidaiyah.

\section{Pendahuluan}

1 - $\begin{aligned} & \text { anusia adalah makhluk beradab yang diciptakan Tuhan. } \\ & \text { Makhluk yang condong kepada kebenaran dan kebaikan. } \\ & \text { Sebagai makhluk beradab, manusia memerlukan }\end{aligned}$ tuntunan untuk membuatnya konsisten terhadap hakekat dirinya.

*Jurusan PAI FITK IAIN Mataram. Email: maimun05@ymail.com 
Pendidikan adalah salah satu wadah untuk menjadikan manusia berada dalam keadaban. Pendidikan merupakan suatu yang niscaya dalam kehidupan manusia dalam mewujudkan dirinya sebagai makhluk beradab dan berbudaya. Permulaan wahyu yang diturunkan Allah kepada Nabi Muhammad SAW dalam al-Qur'an surat Al-Alaq ayat 1-5 yakni "Bacalah dengan menyebut nama Tuhanmu yang menciptakan, Dia telah menciptakan manusia dari segumpal darah, bacalah dan Tuhanmulah yang Maha mulia, yang mengajar (manusia) dengan pena, Dia mengajar manusia apa yang tidak diketahuinya" dapat dijadikan bukti betapa pendidikan itu sangat diperlukan dalam kehidupan manusia.

Pendidikan sebagai sesuatu yang amat diperlukan dalam kehidupan manusia tidak boleh terhenti pada usia tertentu. Pendidikan harus berjalan mengikuti usia manusia sebagaimana disabdakan Nabi Muhammad SAW "Tuntutlah ilmu itu semenjak buaian hingga liang lahat". Artinya pendidikan itu berjalan sepanjang umur manusia (life long learning).

Berpijak dari konsep bahwa pendidikan berlangsung sepanjang usia manusia, maka sejatinya manusia memperoleh pembelajaran yang sesuai dengan tingkat dan situasi pertumbuhan dan perkembangannya. sebagaimana pesan Nabi SAW; "Didiklah anakmu sesuai zamannya, karena dia lahir pada zamannya, bukan pada zaman kamu." Orang tua setidaknya harus memahami hal ini, karena merekalah yang mengawal kehidupan anaknya semenjak lahir. Dalam konteks yang lain Nabi Muhammad SAW bersabda dalam salah satu haditsnya; "Manusia lahir dalam keadaan suci, orang tuanyalah yang membuat dia Yahudi, Nasrani, atau Majusi."

Pendidikan merupakan wahana untuk mencerdaskan kehidupan bangsa sebagaimana diamanatkan dalam Undang-undang bahwa pemerintah berupaya membangun sektor pendidikan secara terencana, terarah, dan bertahap serta terpadu dengan keseluruhan pembangunan kehidupan bangsa, baik ekonomi, ilmu pengetahuan, sosial budaya, dan teknologi.

Sejalan dengan amanah tersebut di atas, tuntutan terhadap pembangunan sektor pendidikan menjadi semakin luas, yakni di 
satu pihak tetap terpenuhinya kesempatan memperoleh pendidikan bagi anak usia sekolah yang jumlahnya semakin bertambah, dan di pihak lain tercapainya efisiensi, relevansi, dan peningkatan mutu pendidikan. Peningkatan mutu pendidikan merupakan hal yang sangat strategis dalam meningkatkan kualitas sumber daya manusia agar memiliki pengetahuan, keterampilan, dan sikap yang berorientasi pada peningkatan penguasaan ilmu pengetahuan dan teknologi, kemampuan profesional, dan produktivitas kerja sesuai dengan kebutuhan pembangunan bangsa.

Peranan pendidikan Islam sangat penting dalam mewujudkan amanah yang terurai di atas. Mengelola suatu lembaga pendidikan Islam (madrasah) bukanlah hal yang mudah. Apalagi yang dimaksud mengelola tidak sekedar dalam pengertian mempertahankan yang sudah ada, tetapi melakukan pengembangan secara sistematik dan sistemik, yang meliputi aspek ideologis (visi dan misi), kelembagaan dan langkah operasional serta mencerminkan pertumbuhan (growth), perubahan (change) dan pembaharuan (reform).

Pengelolaan madrasah dituntut memiliki kedalaman normatif dan ketajaman visi agar pendidikan selalu dapat berkesinambungan dengan perubahan-perubahan yang terjadi di masa depan, sehingga manusia yang dihasilkan dari pendidikan adalah model manusia yang mempunyai kesiapan dalam menghadapi tantangan masa depan.

Penyelenggaraan pendidikan Islam dilakukan pada berbagai jenjang dan jalur pendidikan, dengan tujuan mengembangkan potensi dan kemampuan peserta didik agar menjadi manusia yang beriman dan bertakwa kepada Allah SWT, berakhlak mulia, sehat, berilmu, cakap, kreatif, mandiri, dan menjadi warga negara yang demokratis dan bertanggungjawab.

Berbagai langkah dan upaya dilakukan pemerintah untuk meningkatkan kualitas Madrasah Ibtidaiyah, antara lain kebijakan Direktorat Jenderal Pendidikan Islam Kementerian Agama tentang rencana strategi pembangunan pendidikan Islam terdiri dari: (1) Perluasan dan pemerataan akses pendidikan, (2) Peningkatan mutu, 
relevansi dan daya saing, dan (3) Peningkatan tata kelola, akuntabilitas dan pencitraan. Tiga kebijakan strategis di atas ditujukan secara khusus untuk: Pertama, mempertegas keberpihakan pada peserta didik dari kalangan masyarakat kurang beruntung secara ekonomi dan lembaga-lembaga pendidikan Islam yang diselenggarakan oleh masyarakat (swasta). Kedua, peningkatan mutu pendidikan yang berorientasi pada mutu lulusan dan mutu layanan pendidikan. Ketiga, peningkatan kinerja aparat birokrasi pendidikan Islam melalui paradigma yang berorientasi melayani bukan dilayani.

Disamping itu, untuk peningkatan kualitas Madrasah Ibtidaiyah dilakukan juga program pengembangan "Kelas Unggulan" dengan maksud agar Madrasah Ibtidaiyah dapat menjadi contoh dalam penyelenggaraan madrasah yang berkualitas dan memberi dampak bagi pengembangan Madrasah Ibtidaiyah di sekitarnya. Sasaran kegiatan itu meliputi: (1) pengembangan pembelajaran yang efektif dan efesien, (2) meningkatkan sumber daya pendidikan, dan (3) peningkatan manajemen madrasah untuk penguatan kelembagaan.

Di Kota Mataram hanya ada tiga Madrasah Ibtidaiyah negeri, yakni Madrasah Ibtidaiyah Negeri (MIN) Punia Mataram, MIN Karang Baru Mataram, dan MIN Cakra Barat. Harapannya ketiga madrasah tersebut terjadi peningkatan kualitas dalam penyelenggaraan pendidikan dengan senantiasa memperhatikan kualitas lulusan (output), kualitas sumber daya manusia, menejemen yang kuat dan handal, kualitas sarana dan prasarana serta mutu proses belajar mengajar. Di samping itu, keberhasilan MIN Punia Mataram dalam penyelenggaraan pendidikan madrasah dapat ditularkan terhadap Madrasah Ibtidaiyah lain yang berada di sekitarnya.

Kualitas pendidikan, tidak hanya dinilai oleh kalangan internal Madrasah, tetapi secara luas kualitas pendidikan itu dirasakan dan dinilai oleh masyarakat dan dunia usaha sebagai pengguna hasil (output) dari proses pendidikan.

Upaya peningkatan kualitas pendidikan tidak dapat dilakukan secara parsial tetapi harus dilakukan secara konprehensif atas semua komponen madrasah terlibat didalamnya. Untuk melihat efektivitas 
penyelenggaraan Pembelajaran Kelas Unggulan di MIN Punia Mataram tidak hanya dilihat dari faktor siswa saja tetapi faktor lain harus diperhatikan juga, misalnya: guru dan pegawai, kurikulum, sarana prasarana, kepemimpinan dan manajemen, kegiatan belajar mengajar, dan faktor lainnya.

Dari permasalahan tersebut diatas, maka perlu dilakukan penelitian secara mendalam berupa evaluasi program penyelenggaraan Kelas Unggulan di Madrasah Ibtidaiyah Negeri Punia Mataram.

Evaluasi program didefinisikan sebagai kegiatan sistimatis untuk mengumpulkan, mengolah, menganalisis, dan menyajikan data sebagai masukan untuk pengambilan keputusan. Dalam pandangan teknologi pendidikan, evaluasi mengacu pada suatu upaya menilai dapat tidaknya diterima produk berupa sumber belajar atau komponen sisten instruksional yang telah dihasilkan berdasar kriteria yang ditetapkan oleh fungsi-fungsi lain. berkaitan dengan penelitian ini, peneliti bermaksud mengevaluasi keterlaksanaan program parenting, apakah sudah tercapai indikator yang ada pada buku petunjuk teknis atau belum.

Beberapa model evaluasi dapat digunakan untuk mengevaluasi penyelenggaraan program kelas unggulan. Pemilihan model evaluasi yang tepat akan sangat mempengaruhi hasil evaluasi yang dilakukan, sehingga hasil evaluasi tersebut dapat memberikan kontribusi yang positif bagi para pelaksana program. Salah satu model evaluasi yang dapat digunakan untuk menganalisis tingkat keberhasilan penyelenggaraan program pendidikan keorangtuaan/parenting adalah model yang dikembangkan oleh Stufflebeam (1965), yaitu model CIPP (Contexs, Input, Process, dan Product).

\section{Latar Belakang dan Landasan Formal Dilaksanakan Kelas Unggulan di Madrasah Ibtidaiyah Negeri Punia Mataram}

Kelas unggulan adalah kelas yang dikembangkan untuk mencapai keunggulan dalam keluaran (out put) pendidikannya. Untuk mencapai keunggulan tersebut, maka masukan (input), proses 
pendidikan, guru dan tenaga kependidikan, manajemen, layanan pendidikan, serta sarana penunjangnya harus diarahkan untuk menunjang tercapainya tujuan tersebut (Depdikbud, 1994).

Program kelas unggulan di MIN Punia Mataram telah berlangsung sejak tahun 2014. Dan pada awalnya di uji cobakan pada kelas 3 dan kelas 4. Adapun yang merlatarbelakangi dilaksanakannya program ini adalah keinginan pihak sekolah agar supaya anak-anak didik yang memiliki prestasi dapat dikumpulkan menjadi satu, sehingga akan mendapatkan output yang maksimal. Hal tersebut sesuai dengan konsep bahwa kelas Unggulan adalah program unggulan yang lahir dari sebuah keinginan untuk memiliki kelas yang mampu berprestasi dalam penguasaan ilmu pengetahuan dan teknologi ditunjang oleh akhlakul karimah (Depag RI, 2004:41).

Lebih lanjut, unggulan juga dipahami sebagai kelas yang merupakan suatu unit kecil siswa memiliki situasi sosial yang bebeda-beda antar kelas yang satu dengan kelas yang lain. Karena itu, supaya tujuan pembelajaran dapat dicapai secara maksimal, maka ada sekolah yang dengan sengaja mengklasifikasikan siswa atas dasar kemampuan tertentu yang dimiliki siswa ke dalam suatu kelas yang lazim dinamakan sebagai kelas favorit atau kelas unggulan, sekalipun langkah ini seharusnya secarfa filosofis dapat dipandang sebagai langkah yang mengandung kenegatifan bagi pergaulan antar siswa, yakni ada siswa yang merasa berada pada kelas superior sekaligus ada siswa yang merasa berada pada kelas inferior, sehingga pemisahan siswa ini dapat dinilai mengabaikan prinsip persamaan di antara seluruh manusia (Ali Rohmad, 70).

Pelaksanaan program unggulan di MIN Punia terilhami oleh sebuah filosofi yang mengatakan 'Lebih Baik Hujan di Satu Tempat dari pada Gerimis di Banyak Tempat' dengan prinsip tersebut, pihak sekolah selanjutnya memberikan treatment kepada sekelompok siswa tertentu dengan harapan memiliki daya ungkit bagi kelas yang lain, sebagai contoh prestasi akademik dapat dijadikan motivasi bagi siswa reguler. 
Di sisi lain keberadaan program kelas unggulan ini pada perjalannya tidak terlepas dari dukungan orang tua siswa, di mana orang tua dengan sukarela mengantarkan konsumsi kepada anaknya seperi rantangan, nasi bungkus dan nasi kotak, mereka juga aktif mencari guru yang dapat memberikan privat bagi anaknya di rumah. Di samping itu tanggapan dari orang tua tentang program kelas unggulan ini sangat baik dan ditunjukkan dengan berbagai cara/dukungan baik materi maupun perhatian kepada siswa. Orang tua yang memiliki anak yang ada pada kelas unggulan lebih mudah diajak diskusi oleh pihak sekolah dan mereka sangat antusias. Orang tua juga dengan senang hati menunggu anaknya, karena memang anak yang mengikuti kelas unggulan tersebut biasanya pulang lebih telat dibanding dengan siswa yang ada dikelas reguler. Bentuk partisipasi orang tua yang lain berupa penambahan operasional dalam rangka menyiapkan sarana dan prasaran penunjang yang tidak dapat dipenuhi oleh sekolah. Hal senada diungkapkan oleh Bafadhal, bahwasannya untuk mencapai kelas yang unggul dituntut adanya tenaga, fasilitas, dan dana yang memadai, dan tidak semua sekolah/madrasah dapat memenuhinya. Secara teknis, pengembangan Kelas Unggulan menuntut adanya tenaga yang profesional dan fasilitas yang memadai. Konsekuensinya dibutuhkan biaya yang tidak sedikit untuk pengembangannya, sehingga uang gedung, SPP juga menjadi mahal yang hanya mampu dipenuhi oleh orang-orang kaya, dan kecil sekali kemungkinan bagi orang yang tidak mampu untuk membiayai anaknya di kelas unggulan (Bafadhal, 2003:28).

\section{Prosedur Rekrutmen Peserta Didik, Pemenuhan Tenaga Pendidik, Manajemen Kelas, Kurikulum, Sarana Prasarana, dan Dukungan Masyarakat terhadap Kelas Unggulan di Madrasah Ibtidaiyah Negeri Punia Mataram}

Dalam pelaksanaan program kelas unggulan, pihak MIN Punia setidaknya memperhatikan beberapa hal, di antaranya: prosedur rekrutmen peserta didik, pemenuhan tenaga pendidik, manajemen kelas, kurikulum, sarana prasarana, dan dukungan masyarakat. 
Berikut akan dijelaskan secara rinci temuan-temuan di lapangan terkait dengan hal-hal tersebut:

1. Sosialisasi mengenai akan dilaksanaknnya program kelas unggulan dilakukan terbatas hanya di internal guru, sehingga dari sosialisasi tersebut diperoleh kesepakatan bersama dengan semua dewan guru, berdasarkan kesepakatan tersebut maka dilaksanakanlah program tersebut.

2. Setelah kesepakatan dengan guru dibuat, langkah selanjutnya adalah pihak sekolah mengundang orang tua murid dalam rangka sosialisasi pembentukan kelas unggulan

3. Pada awalanya peserta kelas unggulan di MIN Punia Mataram adalah anak-anak yang memiliki prestasi di kelas yakni rangking 1-3 saja dengan tetap memperhatikan kesanggupan dari anak tersebut.

4. Rekrutmen tenaga pengajar pada kelas unggulan dilakukan dengan cara meminta kesediaan dewan guru yang sudah terbiasa menjadi tenaga pengajar bagi siswa yang akan mengikuti Olimpiade. Di samping itu Pihak sekolah juga melakukan kerja sama dengan salah satu perguruan tinggi, lembaga BIMBEL bahasa asing (Bahasa Arab dan Bahasa Inggris) yang ada di Kota Mataram dalam rangka menyiapkan tenaga pendidik pada kelas unggulan.

5. Penjadwalan belajar siswa yang mengikuti program kelas unggulan dibedakan dengan siswa yang berada pada kelas reguler, dan jadwal tambahan diberikan hanya kepada siswa yang mengikuti kelas unnggulan yakni pada sore hari setelah jam kelas reguler berakhir.

6. Mata Pelajaran yang diajarkan pada siswa yang mengikuti kelas unggulan dan kelas reguler pada dasarnya sama, namun bagi kelas unggulan terdapat sedikit tambahan terutama mata pelajaran IPA dan Matematika untuk keperluan mengikuti Olimpiade, sedangkan mata pelajaran Bahasa Arab dan Bahasa Inggris untuk keperluan komunikasi.

7. Tidak terdapat perbedaan yang begitu menonjol terkait dengan sarana dan prasarana yang ada pada kelas unggulan 
ini, hanya kipas angin supaya angin dapat bersirkulasi dengan baik.

Perencanaan Pembelajaran, Pelaksanaan, Penilaian dan Pengawasan Proses Pembelajaran Berdasarkan Pada Standar Proses Pendidikan Kelas Unggulan di Madrasah Ibtidaiyah Negeri Punia Mataram

Perencanaan pembelajaran (RPP) atau silabus yang digunakan pada program kelas unggulan tidak memiliki perbedaan yang signifikan, anamun terdapat penekanan pada mata pelajaran tertentu seperti penguasaan bahasa dan pendalaman IPA. Di samping itu siswa yang mengikuti program kelas uggulann juga diberikan modul tambahan. Pelaksanaan pembelajaran di kelas unggulan tidak jauh berbeda dengan kelas regular, hanya saja kelas unggulan mendapatkan jam belajar tambahan pada sore hari di mana pada jam tersebut siswa kelas regular sudah pulang. Selanjutnya evaluasi/penilaian dilakukan oleh kepala sekolah selaku pimpinan dan semua dewan guru yang ada. dalam hal evaluasi, kepala sekolah secara langsung menjadi tenaga pengajar pada kelas unggulan trsebut.

\section{Prestasi Belajar Siswa Kelas Unggulan di Madrasah Ibtidaiyah Negeri Punia Mataram}

Program Kelas Unggulan bertujuan untuk menghasilkan kurikulum pendidikan yang memiliki keunggulan dalam hal berikut: a) keimanan dan ketaqwaan kepada Tuhan Yang Maha Esa; b) nasionalisme dan patriotisme yang tinggi; c) wawasan iptek yang mendalam dan luas; d) motivasi dan komitmen yang tinggi untuk mencapai prestasi dan keunggulan; e) kepekaan sosial dan kepemimpinan; dan f) disipin tinggi ditunjang dengan kondisi fisik yang prima (Davis, 1991: 49). Intinya, kelas unggulan bertujuan mencetak peserta didik yang cerdas secara intelektual, cerdas religious, cerdas moral, dan cerdas social.

Menurut Djoyo Negoro (1998:41) ciri-ciri sekolah unggul adalah sekolah yang memiliki indikator, yaitu: (1) prestasi akademik 
dan non-akademik di atas rata-rata sekolah yang ada di daerahnya; (2) sarana dan prasarana dan layanan yang lebih lengkap; (3) sistem pembelajaran lebih baik dan waktu belajar lebih panjang; (4) melakukan seleksi yang cukup ketat terhadap pendaftar; (5) mendapat animo yang besar dari masyarakat, yang dibuktikan banyaknya jumlah pendaftar dibanding dengan kepasitas kelas; (6) biaya sekolah lebih tinggi dari sekolah disekitarnya.

Brdasarkan hasil penelitian tentang komponen produk maka dapat dideskripsikan terdapat perbedaan hasil belajar siswa sebelum dan setelah berlangsungnya kelas unggulan. Keberadaan skelas unggulan juga dapat menjadikan siswa lebih giat dalam berkompetisi dengan temannya. yang paling mencolok dengan keberaddan kelas unggulan ini adalah, di mana siswa yang ranking satu pada kelas reguler jika dikonversikan dengan nilai/rangkin pada kelas unggulan maka siswa tersebut berada pada rangking 17 di kelas unggulan, artinya yang rangking 17 di kelas unggulan jika dibawa kekelasreguler maka siswa tersebut menjadi rangking satu. selanjutnya hal yang tidak kalah penting adalah dengan keberadaan kelas unggulan ini perhatian orang tua meningkat, di mana sebelum kelas unggulan ini ada orang tua bermalas-malasan mengantarkan anknya les, akan tetapi setelah anaknya masuk ke kelas unggulan, mereka berlomba-lomba mendatangkan guru les ke rumahnya.

\section{Catatan Akhir}

Berdasarkhan pembahasan di atas dapat disimpulkan beberapa hal terkait dengan pelaksanaan program kelas unggulan, di antaranya:

Latar belakang dilaksanakannya program kelas unggukan adalah keinginan pihak sekolah agar supaya anak-anak didik yang memiliki prestasi dapat dikumpulkan menjadi satu, sehingga akan mendapatkan output yang maksimal. Pelaksanaan program unggulan di MIN Punia terilhami oleh sebig filosofi yang mengatakan Lebih Baik Hujan di satu Tempat dari pada Gerimis di Banyak Tempat' dengan prinsip tersebut, pihak sekolah selanjutnya memberikan treatment kepada sekelompok siswa tertentu yang 
memiliki kemampuan lebih dilihat dari nilai raport dengan harapan memiliki daya ungkit bagi kelas yang lain, sebagai contoh prestasi akademik dapat dijadikan motivasi bagi siswa reguler.

Pelaksanaan program kelas unggulan di MIN Punia diawali dengan melakukan sosialisasi mengenai akan dilaksanakannya program kelas unggulan dilakukan terbatas hanya di internal guru. Setelah kesepakatan dengan guru dibuat, langkah selanjutnya adalah pihak sekolah mengundang orang tua murid dalam rangka sosialisasi pembentukan kelas unggulan. Rekrutmen tenaga pengajar pada kelas unggulan dilakukan dengan cara meminta kesediaan dewan guru yang sudah terbiasa menjadi tenaga pengajar bagi siswa yang akan mengikuti Olimpiade. Di samping itu, pihak sekolah juga melakukan kerja sama dengan salah satu perguruan tinggi, lembaga BIMBEL bahasa asing (Bahasa Arab dan Bahasa Inggris) yang ada di Kota Mataram dalam rangka menyiapkan tenaga pendidik pada kelas unggulan. Penjadwalan belajar siswa yang mengikuti program kelas unggulan dibedakan dengan siswa yang berada pada kelas reguler, dan jadwal tambahan diberikan hanya kepada siswa yang mengikuti kelas unggulan, yakni pada sore hari setelah jam kelas reguler berakhir. Mata Pelajaran yang diajarkan pada siswa yang mengikuti kelas unggulan dan kelas reguler pada dasarnya sama, namun bagi kelas unggulan terdapat sedikit tambahan terutama mata pelajaran IPA dan Matematika untuk keperluan mengikuti Olimpiade, sedangkan mata pelajaran Bahasa Arab dan Bahasa Inggris untuk keperluan komunikasi.

Pada pelaksanaan proses pembelajaran antara kelas unggulan dan reguler tidak jauh berbeda baik perencanaan, proses pembelajaran, sampai evaluasi. Bedanya hanya pada jam belajar tambahan pada sore hari dimana pada jam tersebut siswa kelas regular sudah pulang, sementara kelas unggulan diberikan waktu belajar hingga pukul 16.30 Wita. Selanjutnya evaluasi/penilaian dilakukan oleh kepala sekolah selaku pimpinan dan semua dewan guru dengan menggunakan standar proses. Dalam hal evaluasi perkembangan jalannya program, kepala sekolah secara langsung 
mengevaluasi sambil menjadi tenaga pengajar pada kelas unggulan tersebut.

Pada komponen produk setelah program kelas unggulan berjalan didapatkan perbedaan yang signifikan terkait hasil belajar siswa antara kelas unggulan dan reguler, di mana nilai rata-rata siswa yang memperoleh rangking kelas di kelas reguler sama rataratanya dengan yang tidak mendapat rangking di kelas unggulan. Dengan demikian keberadaan kelas unggulan dapat menjadikan siswa lebih giat dalam berkompetisi dengan temannya.

Berdasarkan hasil penelitian ini, maka peneliti dapat memberikan beberapa masukan terkait dengan pelaksanaan program kelas unggulan di MIN Punia Kota Mataram, di antaranya:

1. Sarana dan prasarana pendukung kegiatan pembelajaran pada kelas unggulan harus ditambah jumlah dan kualitasnya

2. Karena jam belajar siswa kelas unggulan mengalami penanmahan sampai sore hari maka, ketersediaan fasilitas berupa tempat ibadah dan kantin harus disedikan juga.

3. Tenaga pendidik pada kelas reguler harus ditambah, agar pembelajaran menjadi lebih efektif.

\section{Daftar Pustaka}

Aiken, Lewis R., Rating Scales and Checklist: Evaluation Behavior Personality, and Attitude. New York: John Wiley \& Sons Inc., 1996.

Arikunto, Suharsimi dan Cepi Safrudin Abdul Jabar, Evaluasi Program Pendidikan, Pedoman Teoritis dan Praktis bagi Mahasiswa dan Praktisi Pendidikan. Jakarta: Bumi Aksara, 2008.

Bafadhal, Ibrahim, Manajemen Peningkatan Mutu Sekolah Dasar; dari Sentralisai Menuju Desentralisasi. Jakarta: Bumi Aksara, 2003.

Committee, Joint, Ukuran Baku Untuk Evaluasi Program, Proyek, dan Materi Pendidikan. Semarang: IKIP Semarang Press, 1991. Davis, Ivor K. Pengelolaan Belajar. Jakarta: Rajawali, 1991. 
Dean T. Spaulding, Program Evaluation in Practice: Core Concepts and Examples for Discussion and Analysis. San Fransisco: Jossey-Bass, 2008.

Departemen Agama RI, Desain Pengembangan Madrasah. Jakarta: Direktorat Jenderal Kelembagaan Agama Islam, 2004.

Depdikbud, Pengembangan Sekolah Unggul. Jakarta; Dirjen Disdasmen, 1994.

Direktorat Jenderal Kelembagaan Agama Islam, Pedoman Umum Pengembangan dan Pengelolaan Kelas Unggulan, Jakarta: Departemen Agama RI, 2002.

Djaali, dan Pudji Mulyono, Pengukuran dalam Bidang Pendidikan, Jakarta: Grasindo, 2008.

Fitzpatrick, Jody L., et al., Program Evaluation: Alternative Approaches and Practical Guidelines, edisi ketiga, Boston: Pearson Education, Inc, 2004.

Gronlund, Norman. E., Measurement and Evaluation in Teaching, New York: Macmillan Publishing Company 1981.

Isaac, Stephen dan William B. Michael, Handbook in Research and Evaluation, California: Edits Publisher, 1983.

Kirkpatrick "Model Evaluation" Online; http://en.wikipedia.org/wiki/Donald Kirkpatrick. (diakses 15 Pebruari 2016).

Kirkpatrick "Model Evaluation" online; http://www.kirkpatrickpartners.com/OurPhilosophy/TheKirk patrickModel/tabid/302/Default.aspx. (diakses 15 Pebruari 2016).

Mantja, Kumpulan Karya Tulis Terpublikasi: Manajemen Pendidikan dan Supervisi Pengajaran. Malang: Wineka Media, 2002.

Matthew B. Miles and A. Michael Huberman, Analisis Data Kualitatif, terjemahan Tjetjep Rohendi Rohidi, Jakarta: UI-Press, 1992.

Patton, Michael Quin. Metode Evaluasi Kualitatif, terjemahan Budi Puspo Priyadi, Yogyakarta, Pustaka Pelajar, 2009. 
el-HiKMAH, Vol. 10, No. 2, Desember 2016

Stufflebeam, Daniel L. Stufflebeam dan Anthony J. Shinkfield, Evaluation Theory, Models, \& Applications. San Francisco: JosseyBass, 2007.

Sudijono, Anas, Pengantar Evaluasi Pendidikan, Jakarta: Raja Grasindo Persada, 2008.

Sudjana, Djuju, Evaluasi Program Pendidikan Luar Sekolab Untuk

Pendidikan Nonformal dan Pengembangan Sumber Daya Manusia. Bandung: Remaja Rosdakarya, 2006.

Sugiyono, Statistika Untuk Penelitian, Bandung: Alfabeta, 2009.

Sukmadinata, Nana Syaodih, Metode Penelitian Pendidikan, Bandung: PT Remaja Rosdakarya, 2010.

Tayibnapis, Farida Yusuf, Evaluasi Program dan Isntrumen Evaluasi

Untuk Program Pendidikan dan Penelitian, Jakarta: Rineka Cipta, 2008. 